\title{
Analysis of elementary school teachers' perspectives on STEM implementation
}

\author{
Diah Susanti *, Zuhdan Kun Prasetyo, Heri Retnawati \\ Department of Primary Education, Program Pascasarjana, Universitas Negeri Yogyakarta. \\ Jalan Colombo No. 1, Yogyakarta 55281, Indonesia \\ * Corresponding Author. Email: diahsanti14@gmail.co.id
}

Received: 18 April 2020; Revised: 11 May 2020; Accepted: 26 May 2020

\begin{abstract}
This phenomenological research aims to analyse the elementary teachers perspective in Science, Technology, Engineering, Mathematics (STEM) framework implementation in Indonesia. The research is a phenomenological research focused on the elementary school teachers' perspective on STEM implementation. There are 35 teachers of public and private elementary schools with a more than a year of service period in Yogyakarta, Indonesia were involved in this research. Data collection was conducted by interview, observation, and documentation. Data trustworthiness was achieved by triangulation. Data collecting technique was analyzed by developing themes and sub-themes, analysis data (reducing data), presenting data, and drawing conclusion. The analysis results were used to seek the information related the following aspects: Teachers' knowledge of STEM, benefits of STEM, steps of STEM implementation, assessment of STEM implementation, and teacher readiness to implement STEM. The results showed that the teachers' knowledge in STEM framework was still low and they were not ready to implement STEM for various reasons. This research is expected to be a reference for elementary schools and local government in socializing STEM and to support the STEM implementation in elementary schools.
\end{abstract}

Keywords: STEM, knowledge and teacher readiness, elementary school teachers

How to Cite: Susanti, D., Prasetyo, Z., \& Retnawati, H. (2020). Analysis of elementary school teachers' perspectives on stem implementation. Jurnal Prima Edukasia, 8(1), 40-50. doi:https://doi.org/10.21831/jpe.v8i1.31262

\section{Introduction}

The purpose of integrated learning in $21^{\text {st }}$ century is to equip the students in early age to achieve superior, creative, innovative, and competitive in the future. Science, Technology, Engineering, and Mathematics (STEM) emerges as an approach that integrates more than one subject actually required by the students in creating creativity (Kurup et al., 2019). Achieving success as the main goal of STEM approach needs to involve the teachers, school principals, curriculum organizers, and student participation collaborated as an integral part. Teachers are the most important actors who bring the success of STEM implementation (Dare et al., 2019; Hudha et al., 2019; Kurup et al., 2019). This is the reason why it's important to acknowledge the teachers' perspective, especially on how they implement STEM in daily learning activities. From this, the teachers will know what STEM should be implemented in formal schools.

Patterns and systems of learning in schools are commonly based on the students' need and current education. The students are persuaded to be part of each change in order to be the ones with creativity, innovation, and competitiveness. The schools have a big responsibility to do this (Karisan et al., 2019). The fulfillment of responsibility can be started by preparing the skill and comprehensiveness of teachers in implementing Thematic-Integrative learning and STEM (Adi, 2017). This will help the teachers to be able to directly implement STEM on Thematic-Integrative Learning in elementary schools.

Socialization of STEM implementation in several schools in Indonesia is conducted since 2018. It is carried out in stages, starting from high schools to elementary schools. As the new and socialized approach, STEM has the advantages and disadvantages based on teachers' perspective. In recent days, STEM does not have an appropriate framework yet and even it requires a greater effort to generate the students who are competitive in Science, Technology, Engineering, and Mathematics (Zeidler, 2016). 
STEM approach actually fit 2013 Curriculum. The curriculum focuses on Thematic-Integrative Learning (Zuchdi et al., 2013). The similarity of STEM and Thematic-Integrative Learning that concerns in multidisciplinary science should not make STEM a major obstacle to the implementation of 2013 Curriculum. The socialization of STEM in Indonesia is carried out on the basis of needs of world of education that always tries to improve themselves and creates young, creative, innovative, superior, and competitive individuals.

In the future, more than $60 \%$ of jobs require individual skills related to Science, Technology, Engineering, and Mathematics. Therefore, many countries try to implement STEM in schools and improve STEM literacy since the basic school level (elementary schools) (Adams et al., 2014). STEM implementations are usable in all aspects of life, not merely on education. There are six principals of STEM implementation in basic and middle-level formal educations. These principals are based on the cognitive development and psychomotor of students' age (Kurup et al., 2019). The principals include: learning is a lifelong process; STEM is meaningful learning; STEM is taught based on real conditions of daily life; STEM involves the supports of all educators, parents, and students; STEM will always develop following the technological development trend (Falk \& Needham, 2013). When media and technology play a big role in changing human lives, especially in delivering information and knowledge in schools, STEM is used as a mean of growing skills toward the advance of media and technology, so it is appropriate for the teachers to understand well the concept of STEM implementation. In implementing STEM, the teachers must be equipped with good and correct understanding and skills on STEM and its implementation. From this, this research focuses on the elementary school teachers' understanding on STEM and their readiness in implementing STEM.

Learning in 21 st becomes the hot topic in education and educators today. The learning emphasizes on the aspects on how to think creatively and critically. The learning also focuses on how to solve the problems, how to collaborate, and how to communicate (Labov et al., 2010). Twenty first century's learning integrates a variety of scientific disciplines and it can be implemented through Science Techonology, Engineering, Mathematics (STEM). STEM can be interpreted as a diversity of activities that restructure the traditional learning with lecturing method as the basic invention and project (Breiner et al., 2012). However, most lecturers merely assume STEM as the relationship of four disciplines in one application (Bybee, 2010). Modern concepts reveal that STEM is formed on purpose by connecting four disciplines as a whole that can be used to solve the real world problems (Erviana \& Asmara, 2019; Labov et al., 2010). STEM, in its implementation, can be collaborated with Problem-Based Learning (PBL), Project-Based Learning (PjBL) (Breiner et al., 2012), and discovery. STEM implementation begins with provision of problems/ questions phenomena (Kuenzi, 2011), this is an accordance with the steps of Problem-Based Learning that always starts with giving of problems (Merritt, Lee, Rillero, \& Kinach, 2017; Hariyati \& Tarma, 2018). Furthermore, students are given the opportunity to identify, to analyze, to plan, and to design a project (Sari, 2018). STEM can improve students' literacy of Science, Technology, Engineering, and Mathematics (Bybee, 2013). Literacy of Science includes the student activities in identifying the problems scientifically and implementing it into the real life. Literacy of Technology involves the students in the use of technology. Literacy of Engineering emphasizes the ability of students in designing a project/ problem solving. Literacy of Mathematics concerns on the systematic problem solving and delivery and idea.

Based on those benefits, it's important to make sure that the teaching process is in accordance with the steps of STEM implementation. Learning process includes teacher planning and preparation, learning process, assessment and evaluation process, and the availability of media and learning tools. The achievement of a learning goal is inseparable from the readiness and knowledge of the teachers (Aldahmash et al., 2019; Priatna et al., 2019). The teachers should understand how STEM is implemented in learning process. There are there important things the teachers need to know to create a good nuance to achieve the effective learning goal: understanding how to create a learning plan according to the students' needs and learning goal, understanding the way of designing a fun learning based on the students' character, having skill of managing the class to get a comfortable, fun, and conducive for both the students and the teachers (Wong, Wong, \& Seroyer, 2005). In previous research, it reveals some obstacles of STEM implementation and the obstacles are the teachers get difficulties in integrating STEM into learning materials, the teacher sometimes are not motivated to implement STEM because of the limited understanding of STEM (Allen \& Peterman, 2019; Capobianco, 2011; Corlu et al., 2014; 
Jurnal Prima Edukasia, 8 (1), 2020 - 42

Diah Susanti, Zuhdan Kun Prasetyo, Heri Retnawati

Felix et al., 2010; Fulton \& Britton, 2011; Ming-Chien Hsu et al., 2011; Radloff \& Guzey, 2016). Those obstacles are well connected with the teacher readiness and knowledge about STEM.

In some countries such as US, UK, Western Europe, Canada, Brazil, East and Central Asia, and Australia have implemented STEM for a long time (Marginson et al., 2013). They have conducted STEM assessment. There are some benefits of implementing STEM. First, STEM is more relevant with the real-life problems. Second, STEM reduces the separation of disciplines. Third, STEM gives stimulation of students' experience (Stohlmann et al., 2012). Furthermore, the learning takes the students as the center and can improve the students' way of thinking \& problem solving. The final benefit, STEM can improve the students' comprehension (van den Hurk et al., 2019). Actually, there are more benefits of STEM in learning, like making the students know how to use the technology optimally, students are more independent, students know how to solve the problems and how to think critically, and students are innovative (Becker \& Park, 2011; Priatna et al., 2019; Suwarma et al., 2019). Kennedy and Odell also say that STEM can make the students are motivated and enthusiastic in learning (Kennedy \& Odell, 2014). Benefits and obstacles of STEM implementation can be a reference to socialize STEM in Indonesia (Marginson et al., 2013). The absence of research on identifying the readiness and understanding of elementary school teachers in Indonesia makes this research different from other researches. The purpose of this research is to identify the level of readiness and knowledge of elementary school teachers on STEM implementation. Furthermore this research purposes can be used as the relevance of teaching and learning system activities that are in accordance with the curriculum, the level of needs of students, teachers, and schools in Indonesia, as well as in accordance with advances in technology, science, and mathematics on a global scale and procurement of training assistance and the application of STEM for elementary school teachers.

\section{Method}

This research is categorized as the qualitative research, a type of phenomenology. The research focuses on the knowledge of elementary school teachers related to STEM implementation in Indonesia. In this research, as many as 35 elementary schools ( 13 female teachers and 12 male teachers; G1-G35) from public and private elementary schools in Yogyakarta, Indonesia, were involved. The sample of the research was conducted in random, with a qualification of work period is more than or at least one year. This research was conducted in September-November 2019.

The interviews, observations, and documentations were used to collect the data. The researcher used triangulation to get data validation. The stage in this study are: (1) determined the subject of research, (2) determined the subthemes of interview, (3) interview, (4) analyzed the results of interview. Interview questions created by researchers assisted by STEM education experts. The interview guidelines contained: (1) teachers' knowledge on STEM, (2) benefits of STEM, (3) STEM implementation; (4) project assessment, and (5) teachers readiness.

Analysis techniques were (1) developing themes and sub-themes, (2) analysis data (reducing data), (3) presenting data, and (4) drawing conclusion (Bogdan, 1994). Before starting the session of interview, the researcher informed that this research only focused on the elementary school teachers' knowledge on STEM, STEM implementation, benefits of STEM, STEM obstacles, assessment of STEM/ project, and teacher readiness to implement STEM. Interviews were conducted naturally to obtain valid information. The identity of elementary school teachers is replaced by code to keep it secret.

\section{Result and Discussion}

Result

Researcher used data triangulation to test the validity of the data in this study. Data triangulation is done through observation, interviews, and retrieval of documents to the sources. It aims to obtain complete and reliable data. In addition, the interview guidelines used in this study have been declared valid by expert judgment. Researchers also check to get the right data between the information used and obtained by member check.

After getting data from various sources, then the data is reduced. First, the data is sorted based on themes that have been designed in the study. Second, the data that has been sorted according to the themes will be grouped again into sub-themes. Third, the researcher described the relationship between 
Jurnal Prima Edukasia, 8 (1), 2020 - 43

Diah Susanti, Zuhdan Kun Prasetyo, Heri Retnawati

each research sub-theme. Fourth, the researcher drawed conclusions from all the relationships between the research sub-themes.

The research results inform the elementary school teachers' knowledge on STEM. It has been concluded on STEM definition, STEM benefits, STEM implementations, project assessment, and teacher readiness. The results are as follow.

\section{Elementary School Teacher readiness on STEM}

The results of interviews from 35 elementary school teachers in Province of Yogyakarta show that there are 13 teachers have knowledge on STEM they have from college, conference, internet, teacher group discussion, and scientific articles, while 22 others do not have.

Table 1. Reduction Results Related to Elementary School Teachers' Knowledge on STEM

\begin{tabular}{cll}
\hline No. & \multicolumn{1}{c}{ Sub-Theme } & \multicolumn{1}{c}{ Correlation among Sub-Themes } \\
\hline 1. & $\begin{array}{l}\text { Learning approach that relates Science, Technology, } \\
\text { Engineering, and Mathematics }\end{array}$ & $\begin{array}{l}\text { STEM is a learning approach that involves } \\
\text { several disciplines like Science, } \\
\text { Technology, Engineering, and } \\
\text { 2. } \begin{array}{l}\text { Learning is designed with the project of activities and atics; STEM also uses model and } \\
\text { based on problem solving }\end{array}\end{array}$ \\
$\begin{array}{l}\text { Learning involves strategy and learning model to stimulate } \\
\text { the students having a scientist-like thought. }\end{array}$ & $\begin{array}{l}\text { Matragy that lead to a creation of result/ } \\
\text { problem solving project. }\end{array}$ \\
\hline
\end{tabular}

The Table 1 shows there are 13 elementary school teachers (37\%) have knowledge on STEM. These teachers are able to explain STEM definition correctly. STEM is an approach that integrates multidiscipline: Science, Technology, Engineering, and Mathematics. It also involves the use of model and strategy that leads to a creation of result/ project and problem solving. Others, 22 teachers (63\%), say that they do not have knowledge on STEM.

STEM Benefits

Table 2. Reduction Results Related to STEM Benefits

\begin{tabular}{cll}
\hline No & \multicolumn{1}{c}{ Sub-Theme } & \multicolumn{1}{c}{$\begin{array}{c}\text { Correlation among Sub- } \\
\text { Themes }\end{array}$} \\
\hline 1 & $\begin{array}{l}\text { Improve the skills of problem solving, critical and creative thinking, } \\
\text { and literature on STEM }\end{array}$ & $\begin{array}{l}\text { STEM benefits acknowledged } \\
\text { by the elementary school }\end{array}$ \\
2 & $\begin{array}{l}\text { Improve the students to be active, independent, patient, and motivated } \\
\text { teachers are to improve the } \\
\text { skills, behaviors, and } \\
\text { knowledge. }\end{array}$ \\
\hline
\end{tabular}

Table 3. Reduction Results on STEM Implementation

\begin{tabular}{|c|c|c|}
\hline No. & Sub-Theme & $\begin{array}{l}\text { Correlation among Sub- } \\
\text { Themes }\end{array}$ \\
\hline 1. & $\begin{array}{l}\text { STEM implementation is conducted in the following steps: planning, } \\
\text { implementing, and assessing that integrate Science, Technology, } \\
\text { Engineering, and Mathematics }\end{array}$ & $\begin{array}{l}\text { STEM implementation } \\
\text { consists of plan, } \\
\text { implementation, and } \\
\text { assessment. Plan is conducted } \\
\text { by the teachers by considering }\end{array}$ \\
\hline 2. & $\begin{array}{l}\text { Process of STEM implementation is conducted by the teachers; } \\
\text { process of STEM implementation includes model selection, strategy, } \\
\text { and media that will be integrated with STEM }\end{array}$ & $\begin{array}{l}\text { the materials and the students' } \\
\text { needs. STEM implementation } \\
\text { involves the students through }\end{array}$ \\
\hline 3. & STEM planning is based on the students' needs and lec & several activitie \\
\hline 4. & $\begin{array}{l}\text { STEM implementation in elementary schools is integrative learning } \\
\text { that's made based on the theme }\end{array}$ & $\begin{array}{l}\text { experiments, discoveries, and } \\
\text { product creations. STEM }\end{array}$ \\
\hline 5. & $\begin{array}{l}\text { STEM implementation involves many students through many } \\
\text { activities like experiments, discoveries, and product creations }\end{array}$ & $\begin{array}{l}\text { assessment uses the product } \\
\text { assessment and project. }\end{array}$ \\
\hline 6. & STEM assessment uses the project assessment and products & \\
\hline
\end{tabular}

From the interviews with a theme: STEM benefits, the results are as follow (Table 2). The results of interview show that the teachers' feedback states that STEM is to create a fun learning. It fits the elementary schools (Santrock, 2010). Besides, STEM can also develop $21^{\text {st }}$ skills like being creative and critical, able to solve the problems, able to collaborate with others, and having good literacy. 
Jurnal Prima Edukasia, 8 (1), 2020 - 44

Diah Susanti, Zuhdan Kun Prasetyo, Heri Retnawati

\section{Teachers' Knowledge Related to STEM Implementation}

The next interview session, the researcher look for the information of what the teachers' knowledge level is when it's related to STEM implementation. STEM implementation is set as the third theme in this research. The results of the interview can be seen in the Table 3.

Table 3 informs that the elementary school teachers have the basic knowledge of STEM implementation. STEM can be collaborated with problem-based learning, project, and discoveries. The teachers acknowledge how to start learning activity with STEM implementation. The teachers' knowledge on STEM implementation is merely on giving problem then how the students solve it. The teachers do not know yet how to use the four disciplines integrated in STEM.

\section{Teachers' Knowledge on Project-Based Assessment}

Project-Based Assessment is authentic and contextual. Teacher's knowledge on Project-Based Assessment becomes the sub-theme of the fourth question in this research. From the interview, it can be informed that most of the elementary school teachers define project assessment as the final result which is the product or problem solving. This is absolutely different with the existing theory. Project-Based Assessment not only makes the final product a reference of assessment, but the assessment is also carried out holistically. That assessment is started from the process of students in identifying the problems, planning the problem solving, collaborating with friends through the discussion, creating the product or searching the problem solving, doing remedy, and presenting the product result.

The results inform that the elementary school teachers have not been able to distinguish the instruments used to measure the project-based learning. Most teachers' answers are merely limited to the project as a result. However, some teachers answer, "I used to use the portfolio sheet in K13-based books (books designed according to 2013 Curriculum) to assess the students' projects (G32)". "I just assess the result of the students' project, for example in the activity of making a cube frame. All I see is only the result of the cube that has been made, I do not make an assessment of how the students can make a cube frame" (G2). Results of interview of how teachers know about the project assessment can be seen in Table 4.

Table 4. Reduction Results on Project-Based Assessment

\begin{tabular}{|c|c|c|}
\hline No. & Sub-Theme & Correlation among Sub-Themes \\
\hline 1. & Assessment on the project done by the students & Project-Based Assessment is a \\
\hline 2. & Assessment based on the product/ result created by the students & process of assessment done by the \\
\hline 3. & $\begin{array}{l}\text { Process of assessment starts from planning to finding the result } \\
\text { done by the students }\end{array}$ & $\begin{array}{l}\text { students, starting from planning to } \\
\text { finding the results and assessment of }\end{array}$ \\
\hline 4. & $\begin{array}{l}\text { Assessment project involves the assessment of the competency } \\
\text { of students' behavior competency, skill, and knowledge }\end{array}$ & $\begin{array}{l}\text { the competency of students' } \\
\text { behavior, skill, and knowledge }\end{array}$ \\
\hline 5. & Assessment can be conducted via checklist sheet and portfolio & \\
\hline
\end{tabular}

Level of Teacher Readiness in Implementing STEM Framework

Based on the interview, the researcher asks the question: are the teachers ready to implement STEM framework in elementary schools. The researcher classifies the teacher readiness into three categories: ready, hesitant, and not ready. Result of elementary school teachers' answers about the readiness in implementing STEM framework is displayed in the Figure 1.

From the Figure 1, the researcher informs that the elementary school teachers who are not ready to implement STEM framework are 29 teachers, larger than the number of teachers who are ready to implement STEM framework (5 teachers). The data is supported by several reasons: (1) time and cost, (2) the limited human resources and technology like internet, (3) orientation of education in Indonesia that's still focusing on students' cognition, (4) difficulties in adjusting the existing curriculum (2013 Curriculum). The researcher also tries to dig the opinion from the elementary school teachers deeper especially related to the obstacles probably appear when implementing STEM in classrooms. The results of interview related this case have been written as follow (Table 5).

The various obstacles experienced by the elementary school teachers indicate that there is Indonesia needs to socialize STEM to the elementary school teachers, especially elementary schools teachers in Yogyakarta. 


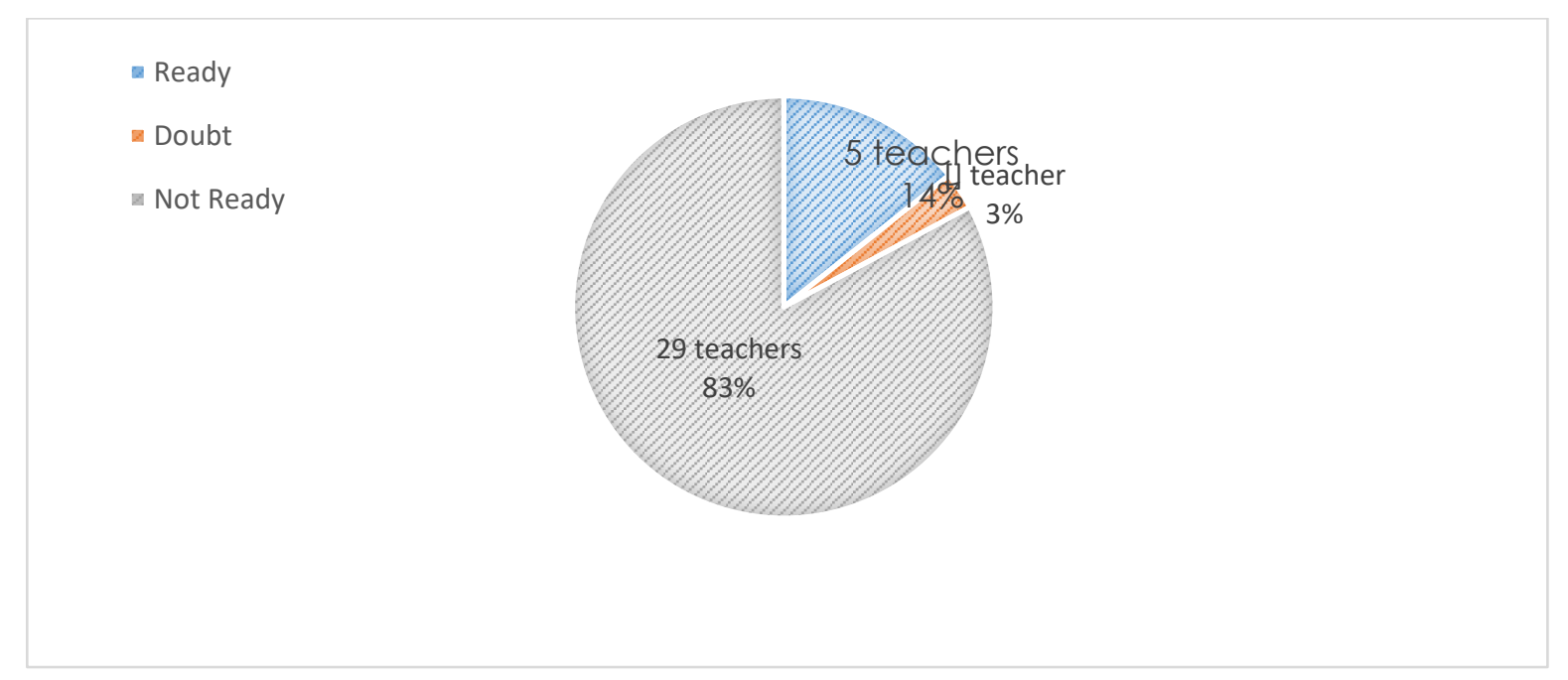

Figure 1. Level of Elementary School Teacher Readiness in Implementing STEM Framework

Table 5. Reduction Results Related to the Obstacles of STEM Implementation in Elementary Schools

\begin{tabular}{|c|c|c|}
\hline No & Responses of Elementary School Teachers & Correlation among The Sub-Themes \\
\hline 1. & $\begin{array}{l}\text { The elementary schools have not supported STEM } \\
\text { implementation yet, for example: the schools do not provide the } \\
\text { media and source of learning that leads to technology use }\end{array}$ & $\begin{array}{l}\text { The challenges experienced by the } \\
\text { teachers include the lack of } \\
\text { maximum support from schools in }\end{array}$ \\
\hline 2. & $\begin{array}{l}\text { There are many teachers over } 40 \text { years-old who experience the } \\
\text { difficulties in using technology as the part of STEM } \\
\text { implementation }\end{array}$ & $\begin{array}{l}\text { providing medias and learning } \\
\text { sources as well as STEM training, } \\
\text { technological and technical }\end{array}$ \\
\hline 3. & $\begin{array}{l}\text { It needs a technique integration (part of STEM) in } 2013 \\
\text { Curriculum in the elementary schools }\end{array}$ & $\begin{array}{l}\text { difficulties in } 2013 \text { Curriculum, } \\
\text { amount of cost and time, and }\end{array}$ \\
\hline 4. & It needs amount of cost and time to implement STEM & administrative matters in \\
\hline 5. & $\begin{array}{l}\text { Teachers' duty in completing the administration of leaning } \\
\text { makes them only focus on the administrative matters, so the } \\
\text { teachers have more burden when new policies emerge, like } \\
\text { STEM implementation }\end{array}$ & implementing STEM. \\
\hline 6. & $\begin{array}{l}\text { The needs of elementary schools in Indonesia are not yet in line } \\
\text { with STEM implementation }\end{array}$ & \\
\hline 7. & $\begin{array}{l}\text { Ujian Nasional (standard examination in Indonesia) prioritizes } \\
\text { the students' cognitive capability, but STEM focuses more on } \\
\text { skills owned by the students }\end{array}$ & \\
\hline 8. & $\begin{array}{l}\text { Lack of STEM training for teachers, so it's difficult for the } \\
\text { teachers to implement STEM. }\end{array}$ & \\
\hline
\end{tabular}

Discussion

The launching of 21st Century's learning affects many countries especially in improving the education in each country. It's characterized by integrated learning (Centeno \& Sompong, 2012; Demirel, 2009). In line with the integrated learning, Indonesia, as the developing country, has created a curriculum that integrates several disciplines or subjects into a form of unity with some particular themes (Dewi \& Rukmini, 2019; Retnawati, 2016). In relation to integrated learning, STEM emerges as an approach that integrates several disciplines: Science, Technology, Engineering, and Mathematics (English, 2017; Siew et al., 2015). This research focuses on teacher knowledge. Based on Bloom's revised taxonomy, there are competency categories divided into some levels: remember, understand, apply, analyze, evaluate, and create (Krathwohl, 2002). The tested component of knowledge in this research is in level 2, understand. Understanding is divided into: interpreting, giving examples, classifying, concluding, comparing, and explaining (Krathwohl, 2002; Pimthong \& Williams, 2018).

The research results reveal that there are 22 teachers who do not have knowledge about STEM (G2, G3, G7, G8, G10, G14, G15, G16, G17, G19, G23, G24, G25, G26, G27, G28, G29, G30, G31, G32, G33, G34, and G35), while the other thirteen teachers have knowledge about STEM. G5 says that the knowledge of STEM is obtained from the social media and scientific articles. G18 also gains 
knowledge of STEM from the teacher group discussion and lectured materials. Only one teacher (G11) says that he has attended STEM training organized by Yogyakarta Education Office. From the interviews, there are 22 teachers express that they do not have knowledge about STEM; even they give the same answers: what is STEM? Sorry I have never heard it before (G17).

The teachers who have knowledge about STEM inform that socialization of STEM in Yogyakarta is not comprehensive yet. Socializing STEM is important and needs to do systematically and effectively (Mathis et al., 2017; Retnawati et al., 2017). The teachers who are the participants of socialization are expected to fully understand the definition, implementation, and assessment of STEM if the socialization has good quality (Retnawati, 2016).

According to elementary school teachers' perspective, STEM is a learning that integrates Science, Technology, Engineering, and Mathematics (G12). STEM refers to Problem-Based Learning and project (G5 and G18). STEM implementation begins with a problem given by the teacher, then the students have the opportunity to investigate and to find the problem. Next, the students formulate the idea of problem solving in group. Finally, the students communicate the results of the discussion (G21). This statement is similar to the theory in Schnittka, 2017 that says STEM begins with a problem and it ends with a discovery on Google as the problem solving. The real STEM implementation based on theories and researches before is distinguished in two ways (Hudha et al., 2019; Johnson et al., 2015). The first one is by focusing one discipline as the concept and other three disciplines are just the applications. For example, in thematic learning, there are two disciplines: Science and Art. In this learning process, the teacher can make Science as a concept, while Mathematics, Engineering, and Technology can be used as the applications or scientific content that can help the students understand the concept of science and art. The second way is by choosing two STEM content variations: Science and Mathematics, Mathematics and Technology, Engineering and Mathematics, Science and Technology, and others. What needs to be emphasized for elementary school teachers is the selection of appropriate themes that can be implemented via STEM. This is important because not all themes in 2013 Curriculum, specifically in elementary schools, can be integrated with STEM.

Furthermore, elementary school teachers define Project-Based ASssessment that's included in sub-theme of interviews. Project-based assessment is a kind of assessment based on process and product (project) assessment made by the students (G4). It's also an assessment that refers to the students' products. Project-Based Assessment is an assessment to measure the competency of knowledge, skill, and behavior (G1). According to the teachers' answers, it can be concluded that Project-Based Assessment is the activity of evaluating all student performances including aspects of knowledge, skill, and behavior within a certain period of time. This is similar with the theory stating that the project assessment includes the evaluation of all competencies in the process of an activity to create a thing (Doppelt, 2003). However, most of elementary school teachers give the answers only on how ProjectBased Assessment is generally conducted. There are only two teachers who give the different answers related to the instrument of Project-Based Assessment. The instrument is the portfolio commonly found in the teachers' handle books.

There are STEM benefits acknowledged by the elementary school teachers, and the benefits are to improve the students' skill in solving problems, to improve students' creativity and independence, to make the students more active in learning participation, to give meaningful and interesting learning, to improve literacy of Science, Technology, Engineering, and Mathematics, and to develop the students' systematic \& critical thinking (Mutakinati et al., 2018). The results of interviews related to the elementary school teacher readiness in STEM implementation show that only 14\% (5 teachers) of 35 teachers are ready to implement STEM. There are some reasons why only less number of teachers who are ready to implement STEM, and the reasons are the lack of internet, difficulty of relating 2013 Curriculum to STEM, amount of teaching hours, difficulty in integrating Science, Technology, Engineering, and Mathematics directly (Aldemir \& Kermani, 2017). Various obstacles faced by the elementary school teachers in implementing STEM can be covered with many solutions. The solutions are by improving the teachers' pedagogical competence by organizing long and short-term STEM trainings, paying more attention to facilities and infrastructure, in this case the learning media in schools (Retnawati et al., 2018). 
Jurnal Prima Edukasia, 8 (1), 2020 - 47

Diah Susanti, Zuhdan Kun Prasetyo, Heri Retnawati

\section{Conclusions}

The results of the research show that there are many teachers in elementary schools who have known yet about STEM because of lack of STEM socialization. From 35 teachers (correspondents) involved in this research, there is only one teacher (correspondent) who has attended to STEM training. Eleven teachers get knowledge about STEM from scientific articles, lecture materials, internet, and teacher discussions. Based on STEM benefits, the elementary school teachers believe that STEM designed systematic and supported with qualified facilities and infrastructures will help the students to achieve the goals, creative thinking and problem solving.

Although the elementary school teachers know that STEM brings more benefits, they prefer to use Problem-Based Learning (PBL), Project-Based Learning (PjBL), and discovery (inquiry learning) without integrating four disciplines: Science, Technology, Engineering, and Mathematics. They also still have difficulty in understanding how to implement STEM in the classroom. The teacher readiness in implementing STEM is also still in low level. Based on the results of the interviews, it can be concluded that the elementary school teachers in Yogyakarta are not ready to implement STEM. Innovations of the transformation in education will not be successful without a big support from the government and schools. In further, the results of the research can be a reference for the educational authority at the level of elementary school to organize STEM training continually. The socialization must be supported by providing the facilities, infrastructures, and human resources in implementing STEM. In addition, this research can be used as a basis for further researches in the form of the effectiveness of STEM training, development of tools, and learning medias that are compatible with STEM.

\section{Acknowledgements}

The researcher says many thanks to Lembaga Pengelola Dana Pendidikan (LPDP) for supporting the research funds, beloved alumnus of Yogyakarta State University where the researcher studies, and to the respondents (the elementary school teachers in Yogyakarrta) who sincerely share their time and big assistance, so the researcher can accomplish her research.

\section{References}

Adams, A. E., Miller, B. G., Saul, M., \& Pegg, J. (2014). Supporting elementary pre-service teachers to teach STEM through place-based teaching and learning experiences. Electronic Journal of Science Education, 18(5), 1-22. https://ejse.southwestern.edu/article/view/12958

Adi, Y. K. (2017). A content analysis of thematic-integrative, scientific approach, and authentic assessment in the second grade of elementary school textbook theme 6. Jurnal Prima Edukasia, 5(2), 211-224. https://doi.org/10.21831/jpe.v5i2.9393

Aldahmash, A. H., Alamri, N. M., \& Aljallal, M. A. (2019). Saudi Arabian science and mathematics teachers' attitudes toward integrating STEM in teaching before and after participating in a professional development program. Cogent Education, 6(1), 1-21. https://doi.org/10.1080/2331186X.2019.1580852

Aldemir, J., \& Kermani, H. (2017). Integrated STEM curriculum: improving educational outcomes for Head Start children. Early Child Development and Care, 187(11), 1694-1706. https://doi.org/10.1080/03004430.2016.1185102

Allen, S., \& Peterman, K. (2019). Evaluating informal STEM education: Issues and challenges in context. New Directions for Evaluation, 2019(161), 17-33. https://doi.org/10.1002/ev.20354

Becker, K. H., \& Park, K. (2011). Effects of integrative approaches among science, technology, engineering, and mathematics (STEM) subjects on students' learning: A preliminary metaanalysis. Journal of STEM Education: Innovations \& Research, $12(5$ \& 6), 23-37. https://www.jstem.org/jstem/index.php/JSTEM/article/view/1509

Bogdan, R. B. S. (1994). Investigação qualitativa em Educação: Uma introdução à teoria e aos métodos. Porto Editora. https://ria.ufrn.br/123456789/1119

Breiner, J. M., Harkness, S. S., Johnson, C. C., \& Koehler, C. M. (2012). What is STEM? A discussion about conceptions of STEM in education and partnerships. School Science and Mathematics, 112(1), 3-11. https://doi.org/10.1111/j.1949-8594.2011.00109.x 
Bybee, B. R. W. (2010). Advancing STEM education: A 2020 vision. Technology and Engineering Teacher, 70(1), 30-36.

Bybee, R. W. (2013). The case for STEM education: Challenges and opportunity. National Science Teachers Association (NSTA) Press.

Capobianco, B. M. (2011). Exploring a science teacher's uncertainty with integrating engineering design: An action research study. Journal of Science Teacher Education, 22(7), 645-660. https://doi.org/10.1007/s10972-010-9203-2

Centeno, E. G., \& Sompong, N. (2012). Technology and learning styles in the GE classroom: Towards developing blended learning systems for the 21st century learner. British Journal of Arts and Social Sciences, 9, 240-256.

Corlu, M. S., Capraro, R. M., \& Capraro, M. M. (2014). Introducing STEM education implications for educating our teachers for the age of innovation. Education and Science, 39(171), 74-85. http://hdl.handle.net/11693/13203

Dare, E. A., Ring-Whalen, A, E., \& Roehrig, G. H. (2019). Creating a continuum of STEM models: Exploring how K-12 science teachers conceptualize STEM education. International Journal of Science Education, 41(12), 1701-1720. https://doi.org/10.1080/09500693.2019.1638531

Demirel, M. (2009). Lifelong learning and schools in the twenty-first century. Procedia - Social and Behavioral Sciences, 1(1), 1709-1716. https://doi.org/10.1016/j.sbspro.2009.01.303

Dewi, R. A. K., \& Rukmini, P. (2019). The effect of thematic learning by using a scientific approach to increase the multiple intelligence of students. Jurnal Prima Edukasia, 7(1), 40-46. https://doi.org/10.21831/jpe.v7i1.24326

Doppelt, Y. (2003). Implementation and assessment of project-based learning in a flexible environment. International Journal of Technology and Design Education, 13(3), 255-272. https://doi.org/10.1023/A:1026125427344

English, L. D. (2017). Advancing elementary and middle school STEM education. International Journal of Science and Mathematics Education, 15(S1), 5-24. https://doi.org/10.1007/s10763017-9802-X

Erviana, V. Y., \& Asmara, A. P. (2019). Designing STEM-integrated encyclopedia as the enrichment for elementary school students. Jurnal Prima Edukasia, 7(2), 114-127. https://doi.org/10.21831/jpe.v7i2.26594

Falk, J. H., \& Needham, M. D. (2013). Factors contributing to adult knowledge of science and technology. Journal of Research in Science Teaching, 50(4), 431-452. https://doi.org/10.1002/tea.21080

Felix, A. L., Bandstra, J. Z., \& Strosnider, W. H. J. (2010). Design-based science for STEM student recruitment and teacher professional development. Fall 2010 Mid-Atlantic ASEE Conference.

Fulton, K., \& Britton, T. (2011). STEM teachers in professional learning communities: From good teachers to great teaching. National Commission on Teaching and America's Future.

Hudha, M. N., Triwahyuningtyas, D., Rafikayati, A., Fajaruddin, S., Maryani, I., Widiaty, I., Nandiyanto, A. B. D., Hamidah, I., \& Permanasari, A. (2019). How is STEM learning for children with special needs in Indonesia? Journal of Physics: Conference Series, 1402, 044104. https://doi.org/10.1088/1742-6596/1402/4/044104

Johnson, C. C., Peters-Burton, E. E., \& Moore, T. J. (2015). STEM road map: A framework for integrated STEM education. Routledge.

Karisan, D., Macalalag, A., \& Johnson, J. (2019). The effect of methods course on pre-service teachers' awareness and intentions of teaching science, technology, engineering, and mathematics (STEM) subjects. International Journal of Research in Education and Science, 5(1), 22-35. https://www.ijres.net/index.php/ijres/article/view/461

Kennedy, T. J., \& Odell, M. R. L. (2014). Engaging students in STEM education. Science Education International, 25(3), 246-258.

Krathwohl, D. R. (2002). A revision of Bloom's taxonomy: An overview. Theory Into Practice, 41(4), 212-218. https://doi.org/10.1207/s15430421tip4104_2 
Kuenzi, J. J. (2011). Science, technology, engineering, and mathematics (STEM) education: Background, federal policy, and legislative action. Congressional Research Service Reports, 3055. https://digitalcommons.unl.edu/crsdocs/35/

Kurup, P. M., Li, X., Powell, G., \& Brown, M. (2019). Building future primary teachers' capacity in STEM: based on a platform of beliefs, understandings and intentions. International Journal of STEM Education, 6(1), 10. https://doi.org/10.1186/s40594-019-0164-5

Labov, J. B., Reid, A. H., \& Yamamoto, K. R. (2010). Integrated biology and undergraduate science education: A new biology education for the twenty-first century? CBE-Life Sciences Education, 9(1), 10-16. https://doi.org/10.1187/cbe.09-12-0092

Marginson, S., Tytler, R., Freeman, B., \& Roberts, K. (2013). STEM: Country comparisons: International comparisons of science, technology, engineering and mathematics (STEM) education. Final report. Australian Council of Learned Academies.

Mathis, C. A., Siverling, E. A., Glancy, A. W., \& Moore, T. J. (2017). Teachers' incorporation of argumentation to support engineering learning in STEM integration curricula. Journal of PreCollege Engineering Education Research (J-PEER), 7(1). https://doi.org/10.7771/21579288.1163

Merritt, J., Lee, M. L., Rillero, P., \& Kinach, B. M. (2017). Problem-based learning in K-8 mathematics and science education: A literature review. Interdisciplinary Journal of ProblemBased Learning, 11(2), 5-17. https://doi.org/10.7771/1541-5015.1674

Ming-Chien Hsu, Purzer, S., \& Cardella, M. E. (2011). Elementary teachers' views about teaching design, engineering, and technology. Journal of Pre-College Engineering Education Research (J-PEER), 1(2). https://doi.org/10.5703/1288284314639

Mutakinati, L., Anwari, I., \& Kumano, Y. (2018). Analysis of students' critical thinking skill of middle school through STEM education project-based learning. Jurnal Pendidikan IPA Indonesia, 7(1), 54-65. https://doi.org/10.15294/jpii.v7i1.10495

Pimthong, P., \& Williams, J. (2018). Preservice teachers' understanding of STEM education. Kasetsart Journal of Social Sciences. https://doi.org/10.1016/j.kjss.2018.07.017

Priatna, N., Martadipura, B. A. P., \& Lorenzia, S. (2019). Development of mathematic's teaching materials using project-based learning integrated STEM. Journal of Physics: Conference Series, 1157(4), 042006. https://doi.org/10.1088/1742-6596/1157/4/042006

Radloff, J., \& Guzey, S. (2016). Investigating preservice STEM teacher conceptions of STEM education. Journal of Science Education and Technology, 25(5), 759-774. https://doi.org/10.1007/s10956-016-9633-5

Retnawati, H. (2016). Hambatan guru matematika sekolah menengah pertama dalam menerapkan kurikulum baru. Jurnal Cakrawala Pendidikan, 3(3). https://doi.org/10.21831/cp.v3i3.7694

Retnawati, H., Djidu, H., Apino, E., \& Anazifa, R. D. (2018). Teachers' knowledge about higher-order thinking skills and. Problems of Education in the 21st Century, 76(2), 215-230.

Retnawati, H., Munadi, S., Arlinwibowo, J., Wulandari, N., \& Sulistyaningsih, E. (2017). Teachers' difficulties in implementing thematic teaching and learning in elementary schools. The New Educational Review, 48(2), 201-212. https://doi.org/10.15804/tner.2017.48.2.16

Santrock, J. W. (2010). Adolescence: An introduction. Brown \& Benchmark.

Sari, I. K. (2018). The effect of problem-based learning and project-based learning on the achievement motivation. Jurnal Prima Edukasia, 6(2), 129-135. https://doi.org/10.21831/jpe.v6i2.17956

Siew, N. M., Amir, N., \& Chong, C. L. (2015). The perceptions of pre-service and in-service teachers regarding a project-based STEM approach to teaching science. SpringerPlus, 4(1), 8. https://doi.org/10.1186/2193-1801-4-8

Stohlmann, M., Moore, T., \& Roehrig, G. (2012). Considerations for teaching integrated STEM education. Journal of Pre-College Engineering Education Research, 2(1), 28-34. https://doi.org/10.5703/1288284314653

Suwarma, I. R., Kaniawati, I., \& Kaniawati, D. S. (2019). Engaging students in STEM based learning through media and technology. Journal of Physics: Conference Series, 1204(1), 012054. 
Jurnal Prima Edukasia, 8 (1), 2020 - 50

Diah Susanti, Zuhdan Kun Prasetyo, Heri Retnawati

https://doi.org/10.1088/1742-6596/1204/1/012054

van den Hurk, A., Meelissen, M., \& van Langen, A. (2019). Interventions in education to prevent STEM pipeline leakage. International Journal of Science Education, 41(2), 150-164. https://doi.org/10.1080/09500693.2018.1540897

Wong, H. K., Wong, R. T., \& Seroyer, C. (2005). The first days of school: How to be an effective teacher. Harry K. Wong Publications.

Zeidler, D. L. (2016). STEM education: A deficit framework for the twenty first century? A sociocultural socioscientific response. Cultural Studies of Science Education, 11(1), 11-26. https://doi.org/10.1007/s11422-014-9578-Z

Zuchdi, D., Prasetya, Z. K., \& Masruri, M. S. (2013). Model pendidikan karakter terintegrasi dalam pembelajaran dan pengembangan kultur sekolah. Multi Presindo. 